${ }^{3}$ Sjodin, R. A., and Beauge, L. A., J. gen. Physiol., 51, 152S$161 S$ (1968).

${ }^{4}$ Baker, P. F., Blaustein, M. P., Keynes, R. D., Manil, J., Shaw, T. I., and Steinhardt, R. A., J. Physiol., Lond., 200, 459-496 (1969).

' Keynes, R. D., and Steinhardt, R. A., J. Physiol., Lond., 198, 581-600 (1968).

'Garrahan, P. J., and Glynn, I. M., J. Physiol., Lond., 192, 217-235 (1967).

7 Thomas, R. C., J. Physiol., Lond., 201, 495-514 (1969).

${ }^{8}$ Hughes, G. M., and Tauc, L., J. exp. Biol., 40, 469-486 (1963).

9 Thomas, R. C., J. Physiol., Lond., 220, 55-71 (1972).

'o Garrahan, P. J., and Glynn, I. M., J. Physiol., Lond., 192, $159-174$ (1967)

${ }^{11}$ Keynes, R. D., J. Physiol., Lond., 178, 305-325 (1965).

${ }^{12}$ Adrian, R. H., and Slayman, C. L., J. Physiol., Lond., 184, 970-1014 (1966).

${ }^{13}$ Mullins, L. J., and Brinley, F. J., J. gen. Physiol., 53, 704 $740(1969)$

\section{Evolutionary significance of autogenous regulation}

GOLDBERGER $^{1}$ has drawn attention to numerous reports relating both to prokaryote and eukaryote systems in which it has been shown that an enzyme may have, in addition to its own catalytic function, a regulatory role in determining the rate of its own synthesis. He has suggested the term 'autogenous regulation' to describe such situations. The term 'autoregulation' has previously been used by others $^{2,3}$ to describe this general phenomenon. Autogenous regulation is, however, itself an example of a more widespread phenomenon, whereby a protein may have a regulatory function as well as a catalytic or structural role. Thus for example, Slonimski and his coworkers ${ }^{4,5}$ have suggested that in Saccharomyces cerevisiae, iso-2-cytochrome $c$ regulates the synthesis, not of itself, but of iso-1-cytochrome $c$, and I have proposed ${ }^{6}$ that in Aspergillus nidulans, nitrate reductase regulates not only its own synthesis, but also the syntheses of many catabolic enzymes.

In an earlier paper ${ }^{7}$, I speculated briefly on the possible evolutionary significance of this bifunctionality of certain proteins, suggesting that it might be a more widespread phenomenon than was at the time apparent. Now that a number of other similar examples have been reported (see ref. 1 for a list of references), it is worthwhile to develop these speculations further.

I assume that, primitively, enzyme synthesis was unregulated. For regulation to evolve, an element was required which must combine two specificities. It had to be able to interact in some way with the apparatus of gene expression to ensure that the gene product was synthesised only when the environmental conditions of the cell required it. It therefore also had to be able to recognise these environmental conditions. The evolution de novo of such an element, with its two unrelated specificities, would pose problems. There were already present in the cell, however, elements which had one of these functions. At this point, it is simpler to consider the evolution of inducible and repressible systems separately.

For inducible systems, the cell already possessed enzymes which had to recognise their substrates to function and it seems plausible that these would provide a starting point from which evolution could select the second specificity necessary for them to acquire additionally a regulatory function. Although, for inducible systems, an enzyme would be an ideal candidate for evolving the function of regulating its own synthesis, it is by no means the only candidate. Any other protein which interacted either with the substrate of the enzyme whose synthesis is to be regulated, or with some metabolite whose intracellular concentration was correlated with the concentration of that substrate, would also be suitable. This may explain why the natural substrate is not the effector in some inducible systems. Examples of this are xanthine dehydrogenase I in Aspergillus nidulans which is induced by its product uric acid but not by its substrate hypoxanthine ${ }^{x}$, and the Escherichia coli lac system which is induced by allolactose, but not by lactose?

For repressible systems, there would also be a variety of possible candidates already present in the cell, which would be suitable for selection for a regulatory role. These would include any protein which could bind either to the product of the pathway to be repressed, or to some metabolite whose concentration was correlated with the concentration of that product (for example, for some amino acid biosynthetic pathways, the charged amino-acyl tRNA). In several cases it has in fact been found that the first enzyme of the biosynthetic pathway, which recognises the end product or a related metabolite because it is subject to feedback inhibition, also has a regulatory role in determining the rate of synthesis of the enzymes of the pathway ${ }^{\mathrm{I}}$. These findings imply that the evolution of feedback inhibition may have predated repression.

In both inducible and repressible systems, it is possible that selection for the modification of a catalytic protein so that it acquires additionally a regulatory function, may in some cases put demands on that protein such that it could perform neither catalysis nor regulation well. In such cases, duplication of the gene specifying the protein, and subsequent divergence of the two gene copies, would allow each to be selected for one of the functions only. This would result in genes whose protein products would now seem to have only a regulatory function, but it is possible that such proteins might still contain in their amino acid sequences 'fossil' evidence of their evolutionary origin.

Beyrouther, et $a l .^{10}$ have determined the amino acid sequence of the $E$. coli lac repressor, and have found no similarities between it and those parts of the $\beta$-galactosidase sequences which are known. They argued that it was unlikely therefore that the two proteins had evolved from a common ancestor. The lac repressor could have evolved, however, from some other cellular enzyme which bound allolactose.

\section{J. Cove}

\section{Department of Genetics,}

University of Cambridge,

Milton Road,

Cambridge $C B 41 X H, U K$

Received June 10; revised July 25, 1974.

Goldberger, R. F., Science, 183, 810 (1974).

${ }^{2}$ Cove, D. J., and Pateman, J. A., J. Bact., 97, 1374 (1969).

${ }^{3}$ Calhoun, D. H., and Hatfield, G. W., Proc. natn. Acad. Sci., U.S.A., 70, 2757 (1973).

${ }^{4}$ Sels, A. A., Fukuhara, H., Pere, G., and Slonimski, P. P., Biochim. biophys. Acta, 95, 486 (1965).

5 Clavilier, L., Pere, G., and Slonimski, P. P., Molec. Gen. Genetics, 104, 195 (1969).

${ }^{6}$ Cove, D. J., Heredity, 29, 119 (1972).

${ }^{7}$ Cove, D. J., Biochim. biophys. Acta, 113, 51 (1966).

${ }^{8}$ Scazzocchio, C., Molec. Gen. Genetics, 125, 147 (1973).

${ }_{9}^{9}$ Jobe, A., and Bourgeois, S., J. molec. Biol., 69, 397 (1972).

${ }^{10}$ Beyrouther, K., Adler, K., Geisler, N., and Klemm, A., Proc. natn. Acad. Sci., U.S.A., 70, 3576 (1973). 